\title{
Solar system design for water pumping
}

\author{
HADIDI ABDELKADER ${ }^{(1)^{*}}$, YAICHI MOHAMMED ${ }^{(1)}$ \\ 1 Unité de recherche en Energie Renouvelables en milieu saharien, URERMS, Centre de \\ Développement des Energies Renouvelables, CDER, 01000, Adrar, Algeria
}

\begin{abstract}
In our days, it seems to us that nobody can suspect it on the importance of water and energy for the human needs. With technological advances, the energy need does not cease increasing. This problem of energy is even more sensitive in the isolated sites where the use of the traditional resources proves often very expensive. Indeed, several constraints, like the transport of fuel and the routine maintenances of the diesel engines, return the search for an essential alternative energy source for this type of sites. It summer necessary to seek other resources of energy of replacement. Renewable energies, like photovoltaic energy, wind or hydraulic, represent a replacement solution par excellence and they are used more and more in our days more especially as the national territory has one of the solar layers highest with the world. The duration of insolation can reach the 3900 hours/year on the Sahara. The energy acquired daily on a horizontal surface of $1 \mathrm{~m} 2$ is about $5 \mathrm{kWh}$, that is to say meadows of $2263 \mathrm{kWh} / \mathrm{m} 2 /$ year in the south of the country. The photovoltaic energy utilization for pumping of water is well adapted for more the share of the arid and semi-arid areas because of the existence in these areas of an underground hydraulic potential not very major. Another very important coincidence supports the use of this type of energy for the water pumping is that the demand for water, especially in agriculture, reached its maximum in hot weather and dryness where it is precisely the moment when one has access to the maximum of solar energy. The goal to see an outline on the general composition of a photovoltaic system of pumping, as well as the theoretical elements making it possible to dimension the current pumping stations.
\end{abstract}

Keywords: Water, Energies Renewable, Photovoltaic Pumping, Requirement out of water, Agriculture.

*Corresponding author: hadidiabdelkader@gmail.com 


\section{Introduction}

Small-scale pumping is one of the most interesting uses of solar energy. Indeed, the maximum intensity of solar radiation generally corresponds to the period of the most important pumping water requirements. On the other hand, the fact that this energy is available just at the point of use, the farmer is freed from problems related to the supply of fuel, or the existence of easily accessible transmission lines. At present, the main obstacles hampering the use of solar pumps on a larger scale are their high cost and the too-recent nature of this technology. The development of a reliable and reasonably priced solar pump which would be very likely within a few years - could be a blow to agriculture in the third world.

Pumping in the Saharan regions is the only solution for the irrigation of agricultural land and drinking water. As a result of the field experience and the various studies carried out, irrigation by photovoltaic pumping systems is the best way for a rapid development of agriculture in the Saharan regions [1]. Particular attention should be given to this project considered strategic and this for several reasons among them: Richness of the water region at shallow depths $(\mathrm{Pm}=15 \mathrm{~m})$; very large area of land that can be exploited and stability of the population in isolated areas.

\section{Pumping methods}

To pump water with a photovoltaic system, two techniques are possible:

In the first technique, solar energy is consumed in "real time"; This is called "pumping in the sun". This solution requires the storage of water in a tank (water pumped during the day is stored for later use in the evening, for example). The second method is to use energy storage, this time, via batteries. The energy stored in the day can be used later to pump water [2].

\section{Datas and Methodes}

The pumping stations consist of one or more pumps which suck up volumes of water and relieve them under a certain pressure in the pipes of the network (see Figure 1).

\subsection{Solar pump system}

A solar pumping system usually consists of [3]:

The photovoltaic generator, the electric pump unit, control electronics and control and the storage part.

Fig.1. Simplified block diagram pumping PV.

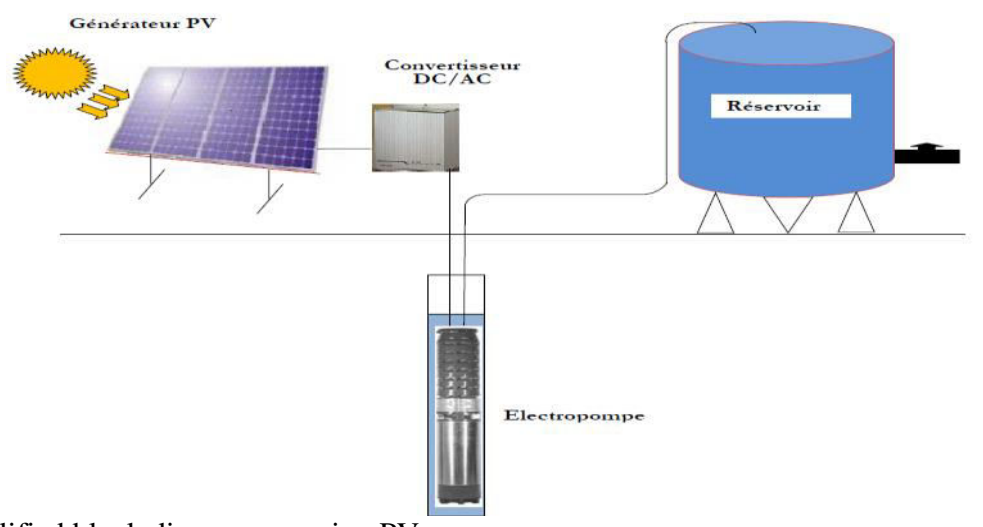




\subsubsection{The photovoltaic generator}

For higher powers, it is necessary to combine serial and parallel multiple modules (Figure 2). In some applications, it is possible to use one or more modules of several tens of cells. For larger applications, the PV generators are grouped in a field of several modules (a few hundred).

The curve of I-V operating a seriated-parallel association of solar modules will have a similar evolution operating in the basic cell curve, but by changing the échèles on both axes. The performance of a PV generator are determined from these curves.

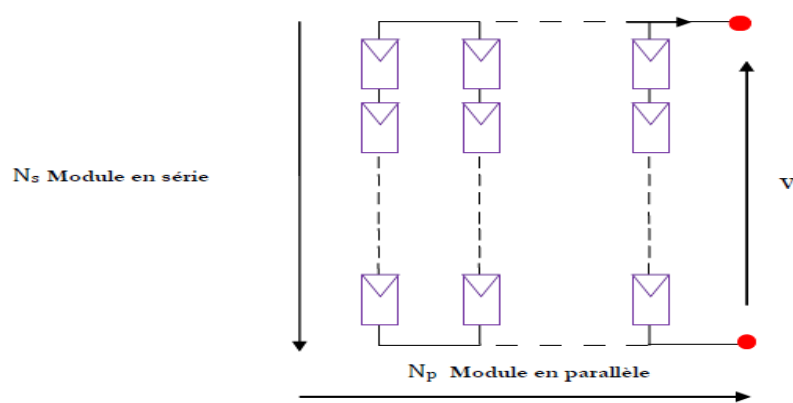

Fig.2. Module Ns put in series and $\mathrm{Np}$ in parallel.

Using this equation below for a mixed group Ns and $\mathrm{Np}$ :

$$
\left.I=N_{p} I_{P h}-N_{P} I_{0}\left[e\left(N_{s} V+\left(I N_{s} R_{s}\right) / \mathrm{N}_{P}\right)-1 / n N_{s} N_{T}\right)\right]-\frac{N_{s} V+I_{s} R_{s} / N_{p}}{\frac{N s R_{p}}{N_{P}}}
$$

\subsubsection{The electric pump unit}

A pump is a device for sucking and discharging a fluid. There are two main types of pumps: centrifugal pumps and positive displacement pumps. These are suitable for raising low water flows at high pressures $[2,4]$.

The centrifugal pump

The centrifugal pump conveys the kinetic energy of the fluid motor by a rotational movement of rotary wheels or fins. The water returns to center of the pump will be pushed outward and upward through the centrifugal force of the blades.

$>$ Characteristics of a centrifugal pump

- Centrifugal pumps are widely used for applications with photovoltaic energy because the couple drive of the pump is zero at start;

- $\quad$ The pump runs with very low sunshine, the motor can provide fast speed nearly constant ;

- Use for high flows.

The parameters necessary to dimension the solar pump are the operating flow and the height at which the pump will have to pump. This is increased by pressure drops and pressure in the pipe. 
The flow delivered by a pump is the amount of water it delivers during a given time interval. In solar pumping, the flow is often expressed in $\mathrm{m} 3$ per day.

\subsection{The general pressure drop}

The general pressure drop depends on:

- The pressure drop is logically directly proportional to the length of the pipe: it increases when the pipe length increases.

- When the diameter decreases, the pressure drop increases considerably. The liquid has more difficulty flowing so friction increases for an identical flow rate.

- The higher the flow rate (higher speed), the greater the frictional forces for the same diameter.

\subsubsection{The total head gauge $\mathrm{Hmt}$}

This is the difference in pressure in meters of water column between the suction and discharge ports. This height can be calculated as follows [5]:

$H m t=H g+\Delta p$

With:

- Hg: Geometric height between the pumped water table (dynamic level) and the utilization plane (see Figure 3). It is calculated by the following formula:

$H g=A+B+C$

- $\Delta \mathrm{pc}$ : Pressure losses produced by the friction of water on the walls of the pipes. They are expressed in meters of water and are a function of distance lines (D), their diameter and the pump capacity.

The calculation of the linear head loss, that corresponding to the general flow in a rectilinear duct, is given by the following this equation:

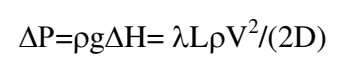

- $\Delta \mathrm{p}$ : linear pressure loss in $\mathrm{Pa}, \lambda$ : pressure loss coefficient (number without dimension), $\mathrm{p}$ : density of water in $\mathrm{kg} / \mathrm{m} 3, \mathrm{~V}$ : flow velocity in $\mathrm{m} / \mathrm{s}$, D: diameter Hydraulic tube in $\mathrm{m}, \mathrm{L}$ : length of tube in $\mathrm{m}$.

- $\mathrm{Ns}=\mathrm{C}+\mathrm{B}$ : The static level in a well or borehole is the distance between the ground and the pump before the water surface. $[3,4]$

- $\mathrm{Nd}=\mathrm{C}+\mathrm{B}+\mathrm{A}$ : The dynamic level of a well or borehole is the distance the soil and the surface of the water for pumping to a given flow rate. For the calculation of the HMT, the dynamic level is calculated for an average flow rate.

- Folding=Nd-Ns: The difference between the dynamic level and the static level.

- Maximum Drawdown: is the maximum acceptable drawdown before stopping the pump. 


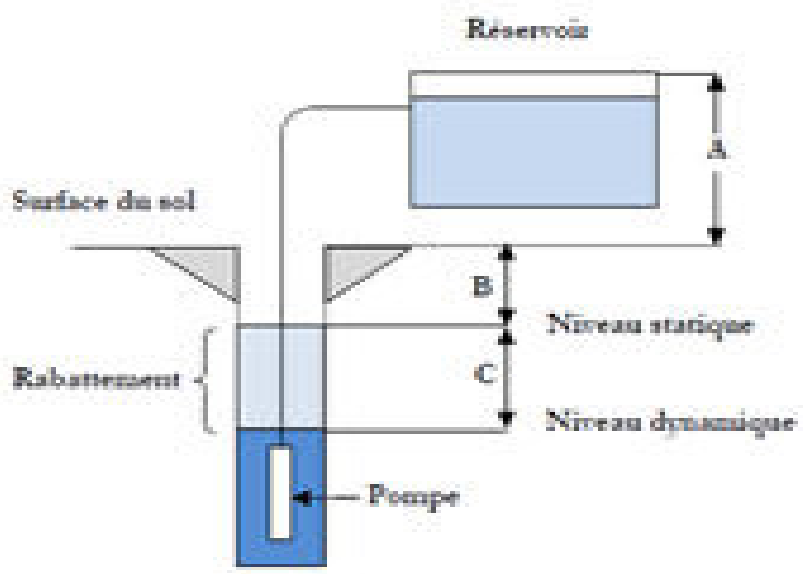

Fig.3. Hauteur gauge total.

\section{Puming System Design}

Two methods are used for sizing photovoltaic pumping systems: an analytical method or graphical method. These methods allow to design a photovoltaic pumping system to meet the water needs of a determined consumption.

\subsection{Graphical method}

These are graphic facilitating direct reading digital calculations. Graphics for spontaneously determine the result of calculations in a system of predefined lines and prepared beforehand, using the performance charts pumps supplied by the manufacturer that provides a function of irradiation overall Pc power required developed by the panels to operate the pump in this range of flow, and Hmt. These are quite handy (Figure 4) and summarize the performance of different pumps for the conditions of their use $[5,6]$. The graphs are operated by a direct reading without having to perform additional plots by reading data directly lying at the intersection of corresponding lines by reading the dot competing in relation to the needs of the speaker. The equipment manufacturers are developing such diagrams based on calculated or measured data. This kind of graphs shows the possible configuration of an electric pump. 


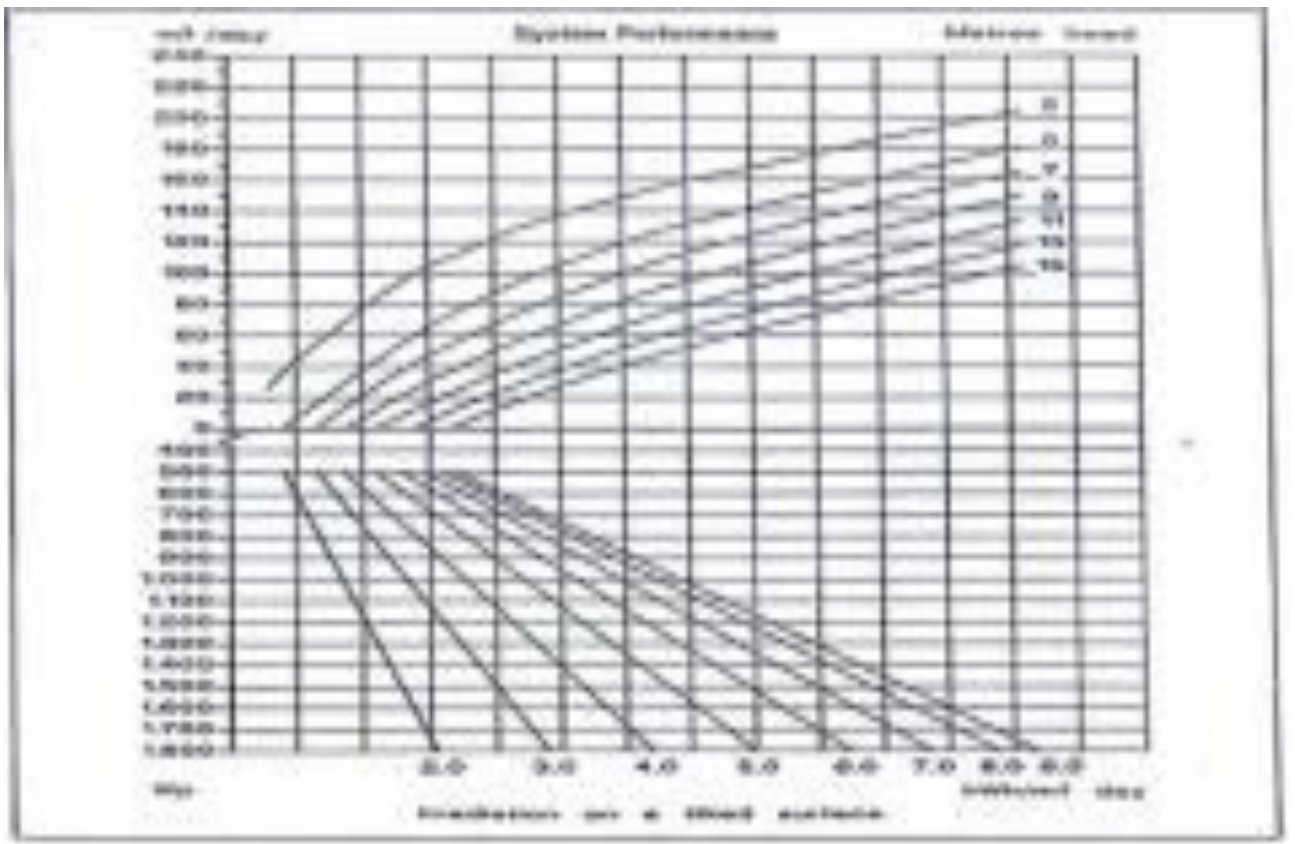

Fig.4. Typical performance curve of pump conditions of use.

\subsection{Analytical method}

The different steps for the design of a pumping system are [5,6]: Assessment of water needs, water power calculation necessary, determination of solar energy available and component selection. Once known the daily volume $\mathrm{Q}$ (m3/day), the total head Hmt and the incident average irradiation $\mathrm{G}$ in terms of generating the corresponding rated power of the photovoltaic generator, $\mathrm{Pc}$ is calculated by the following expression [7] :

\subsubsection{Estimates of water requirements}

For a tropical region, water requirements can be defined using the following values of the Table1.

Table 1. Hydraulic Region data

Humans: 1000hab, Person 5 to 10 liters/day minimum, normal living conditions 30 liters/day

Animals: 100 Sheeps and goats 5 liters/day, 8 Horses 40 liters/day, 2 Ane 20 liters/day, 4 Camel 20 liters/day

Irrigation: Agriculture maraichère $60 \mathrm{~m}^{3} /$ hectare/day for 1 hectare, Rice $100 \mathrm{~m}^{3} / \mathrm{ha} /$ day, cane sugar $65 \mathrm{~m}^{3} /$ ha/day, Cotton $55 \mathrm{~m}^{3} /$ ha/day

We summarize the calculated in Table 2 
Table 2. Water requirements

\begin{tabular}{|c|c|c|c|}
\hline \multicolumn{2}{|c|}{ Number $\mathrm{N}$} & \multicolumn{2}{|c|}{ daily hydraulic Q [ $\mathrm{m}^{3} /$ day] } \\
\hline $\mathrm{N}_{1}$ & 1000 & $\mathrm{Q}_{1}$ & 30 \\
\hline $\mathrm{N}_{2}$ & 100 & $\mathrm{Q}_{2}$ & 0.005 \\
\hline $\mathrm{N}_{3}$ & 8 & $\mathrm{Q}_{3}$ & 0.04 \\
\hline $\mathrm{N}_{4}$ & 2 & $\mathrm{Q}_{4}$ & 0.02 \\
\hline $\mathrm{N}_{5}$ & 4 & $\mathrm{Q}_{5}$ & 0.02 \\
\hline $\mathrm{N}_{6}$ & 0.25 & $\mathrm{Q}_{6}$ & 0.06 \\
\hline $\mathrm{N}_{7}$ & 0.25 & $\mathrm{Q}_{7}$ & 100 \\
\hline $\mathrm{N}_{8}$ & 0.25 & $\mathrm{Q}_{8}$ & 65 \\
\hline $\mathrm{N}_{9}$ & 0.25 & $\mathrm{Q}_{9}$ & 55 \\
\hline
\end{tabular}

$Q=N_{1} Q_{1}+\left(N_{2} Q_{2}+N_{3} Q_{3}+N_{4} Q_{4}+\right)+\left(N_{5} Q_{5}+N_{6} Q_{6}+N_{7} Q_{7}+N_{8} Q_{8}+N_{9} Q_{9}\right)$

$=30+0.5+3.2+0.04+4.2+15+25+16.25+13.7=107.94 m^{3} /$ day

\subsubsection{Calculation of daily hydraulic energy required}

Once the necessary volume of water needs for each month of the year and the characteristics of the well defined, we can calculate hydropower daily and monthly average needed from the relationship [8]:

$E_{h}=$ Ch $\cdot H m t \cdot Q$

with:

Eh: Hydropower kwh/day ; Ch: Constant hydraulic [kg.s.h/m2]=g. $/ 3600$, g: the gravity $(9.81 \mathrm{~m} / \mathrm{s} 2)$, Q: Water volume (m3/day), Hmt: Total height gauge $(\mathrm{m})$ and $\rho$ : Density of water $(1000 \mathrm{~kg} / \mathrm{m} 3)$.

$H \mathrm{mt}=20+10 \% \cdot 20=22 \mathrm{~m}$

$\mathrm{Ch}=9.81 \cdot 1000 / 3600=2.725 \mathrm{~kg} . \mathrm{s} . \mathrm{h} / \mathrm{m} 2$, so $E h=2.725 \cdot 22 \cdot 107.94=6471.001 \mathrm{Wh} /$ day

\subsubsection{Calculation of daily electrical energy required:}

The energy required to raise a certain quantity of water to a certain height during a given day is calculated from the following equation:

$E e=E h /(\eta m p \cdot \eta o n d)$

Where, Ee: Electric energy expressed in kWh/day, ๆmp: The performance of the pump unit, generally between $30 \%$ and $60 \%$, ๆond: The inverter efficiency.

$\eta m p \cdot \eta$ ond $=0.264 \quad$ (we use 0.3 ), So, $\quad E e=6471.001 / 0.3=21750 \mathrm{Wh} /$ day (10)

\subsubsection{Determination of the available solar energy}

The design method used is based on the calculations of monthly daily average values of solar radiation $\mathrm{Gd}$ available to the inclination $\beta$ of the photovoltaic (PV) relative to the horizontal plane. This must be done to maximize the conversion of sunlight into electrical energy $[7,8]$.

In our Région (Adrar province) $\quad G d=5.8 \mathrm{~kW} / \mathrm{m} 2 /$ day

\subsubsection{The Size of the PV array}

The power Pc provided by the PV generator in the measurement standard conditions CSM (Illuminance $(1000 \mathrm{~W} / \mathrm{m} 2)$ and the temperature $25^{\circ} \mathrm{C}$ ) [8]. 
$P c=\eta g \cdot A \cdot G$

with:

Pc: The power output of the generator (W) under MSC (peak power).

ng: The efficiency of the generator to the reference temperature $\left(25^{\circ} \mathrm{C}\right)$.

A: The active area of the generator $(\mathrm{m} 2)$.

$\mathrm{G}$ : The illumination in the MSC conditions.

The daily electrical energy is given by the equation:

$E e=\eta p v \cdot A \cdot G d(\beta) \quad(13)$

npv: The average daily output of the generator in the operating conditions ;

$\operatorname{Gd}(\beta)$ : The average daily radiation incident on the level of modules $\beta$ inclination $(\mathrm{kWh} / \mathrm{m} 2 /$ day $)$

npv: The yield is calculated by the following formula:

$\eta p v=F m(1-\gamma(T-T r) \eta g$

Or :

Fm: Coupling factor, defined as the ratio between the electrical energy generated under the conditions of operation and electric energy that would generate in the system working at maximum power point.

$\gamma$ : Cell temperature coefficient. $\gamma$ assumes values between 0.004 and $0.005 /{ }^{\circ} \mathrm{C}$ for modules in mono and poly crystalline silicon, and 0.001 and 0.002 for amorphous silicon modules.

$\mathrm{T}$ : average temperature of the cells during hours of ensoleillement.

The calculation of power in watts peak.

Substituting equations (9) (12) (13) (14), we obtain the peak power of the generator:

$$
\mathrm{P}_{\mathrm{c}}=\frac{G}{\mathrm{~F}_{\mathrm{m}}\left[1-\gamma\left(\mathrm{T}-\mathrm{T}_{\mathrm{r}}\right)\right] \mathrm{G}_{\mathrm{d}}(\beta)} \cdot \frac{\mathrm{E}_{\mathrm{h}}}{\eta_{\mathrm{MP}} \mathrm{x} \eta_{\text {ond }}}
$$

We can put directly:

$P c=E e /(G d)=21570 /(0.7 \cdot 5.8)=5313 W c$

0.7 : average daily efficiency

We can choose panel PV with her peak power Ps $=75 \mathrm{Wc}$,

Module of total Number puted in series and in parallel $\mathrm{Nt}$

$N t=P c / P s=5313 / 75=71$ module

So we must take the correct $P c=71 \cdot 75=5325 \mathrm{Wc}$

\subsubsection{Pump dimensioning}

The choice of the pump is based on the following two factors: The discharge head and HMT The hourly flow rate $Q h$.

$$
Q_{n}=\frac{Q\left(m^{3} / d a y\right)}{h}
$$

$\mathrm{h}$ : is the number of hours maximum sunshine in $(1000 \mathrm{~W} / \mathrm{m} 2)$

$Q_{h}=107.94 / 5.8=18.61=19 m^{3} / h$ 


\section{Conclusion}

In order to define the useful power to the operation of the pump developed by the solar panels, the minimum data are: The geographical location to determine the overall solar irradiation, the daily water requirements during the maximum need period to determine the flow, the total head to measure the static level, maximum drawdown, tank height and pressure drops due to the piping.

For define the monthly total daily irradiation $\mathrm{kWh} / \mathrm{m} 2 /$ day with respect to the latitude of the working area, choose a pump according to the flow rate and the total head, (use the performance charts of the pumps supplied by the manufacturer), select the inverter suited to the pump (voltage and power), determine the peak power Pc required for the operation of the pump by the analytical or graphic method, select the type of solar panel (set their nominal power Pn), determine the number of panels by Pc/Pn relationship, check the rated voltage for inverter operation (depending on model), determine the number of serial/parallel modules (the connection form).

\section{Bibliographie}

[1] S. LABED, "Le pompage photovoltaïque et le développement des régions sahariennes", Colloque International sur les Ressources en Eau Souterraines dans le Sahara (CIRESS) Ouargla - 12 et 13 décembre 2005. Pompage Photovoltaïque ' Rev. Energ. Ren. Vol. 8 (2005) 19-26.

[2] A. Labonne, "Alimentation d'une pompe à Burkina Faso", 2004.

[3] B. Molle, "Les stations de pompage individuelles pour l'irrigation", juin 1996.

[4] J. Royer, T. Djako, "Le pompage photovoltaïque", Manuel de cours à l'intention des ingénieurs et des techniciens", Université d'Ottawa, 2002.

[5] A. Hadidi, "Synthèse Bibliographie sur le pompage solaire et le dimensionnement de la station de pompage photovoltaïque", Rapport annuel, Mai 2016.

[6] A. Djafour, "Etude d'une station de pompage photovoltaïque dans une région saharienne", Thèse de magistère, université de Ouargla, 2000.

[7] A. Hadj Arab, M. Benghanem et A. Gharbi, "Dimensionnement de Systèmes de Pompage Photovoltaïque", Rev. Energ. Ren. Vol. 8 (2005) 19 - 26.

[8] B. Multon, H. B. Ahmed, N. Bernard, «Les moteurs électriques pour applications de grande série », Pierre-Emmanuel CAVAREC Antenne de Bretagne de l'École Normale Supérieure de Cachan, Revue 3EI juin 2000. 